\title{
Black carbon emissions from Russian diesel sources: case study of Murmansk
}

\author{
M. Evans ${ }^{1}$, N. Kholod ${ }^{1}$, V. Malyshev ${ }^{2}$, S. Tretyakova ${ }^{3}$, E. Gusev² ${ }^{2}$, S. Yu ${ }^{1}$, and A. Barinov ${ }^{2}$ \\ ${ }^{1}$ Joint Global Change Research Institute, Pacific Northwest National Laboratory, \\ 5825 University Research Court, Suite 3500, College Park, MD 20740, USA \\ ${ }^{2}$ Department of Energy and Transport, Murmansk State Technical University, Murmansk, Russian Federation \\ ${ }^{3}$ Department of Environment, Murmansk State Technical University, Murmansk, Russian Federation
}

Correspondence to: M. Evans (m.evans@pnnl.gov)

Received: 25 November 2014 - Published in Atmos. Chem. Phys. Discuss.: 3 February 2015

Revised: 16 June 2015 - Accepted: 4 July 2015 - Published: 27 July 2015

\begin{abstract}
Black carbon (BC) is a potent pollutant because of its effects on climate change, ecosystems and human health. Black carbon has a particularly pronounced impact as a climate forcer in the Arctic because of its effect on snow albedo and cloud formation. We have estimated BC emissions from diesel sources in the Murmansk Region and Murmansk City, the largest city in the world above the Arctic Circle. In this study we developed a detailed inventory of diesel sources including on-road vehicles, off-road transport (mining, locomotives, construction and agriculture), ships and diesel generators. For on-road transport, we conducted several surveys to understand the vehicle fleet and driving patterns, and, for all sources, we also relied on publicly available local data sets and analysis. We calculated that $\mathrm{BC}$ emissions in the Murmansk Region were $0.40 \mathrm{Gg}$ in 2012. The mining industry is the largest source of $\mathrm{BC}$ emissions in the region, emitting $69 \%$ of all BC emissions because of its large diesel consumption and absence of emissions controls. On-road vehicles are the second largest source, emitting about $13 \%$ of emissions. Old heavy duty trucks are the major source of emissions. Emission controls on new vehicles limit total emissions from on-road transportation. Vehicle traffic and fleet surveys show that many of the older cars on the registry are lightly or never used. We also estimated that total $\mathrm{BC}$ emissions from diesel sources in Russia were $50.8 \mathrm{Gg}$ in 2010, and on-road transport contributed $49 \%$ of diesel BC emissions. Agricultural machinery is also a significant source Russia-wide, in part because of the lack of controls on offroad vehicles.
\end{abstract}

\section{Introduction}

Black carbon (BC) is a potent pollutant, with a global warming potential 680 times that of $\mathrm{CO}_{2}$ (on a 100-year basis) (Bond and Sun, 2005). It also contributes to adverse impacts on human health, ecosystems and air visibility. In particular, it is associated with respiratory and cardiovascular effects, as well as premature death. BC is the product of incomplete combustion, resulting in small, light-absorbing particles of 2.5 microns or less. $\mathrm{BC}$ is a major component of $\mathrm{PM}_{2.5}$. Diesel and biomass combustion are both important global sources of $\mathrm{BC}$ and $\mathrm{PM}_{2.5}$ emissions. Black carbon has a particularly pronounced impact as a climate forcer in the Arctic because of its effect on snow albedo and cloud formation (EPA, 2012).

This article provides a detailed inventory of BC emissions from diesel sources in Russia's Murmansk Region. Murmansk City is the largest city in the world above the Arctic Circle. Russian BC emissions are poorly understood in general (Stohl, 2013); this represents an important gap in our understanding of $\mathrm{BC}$ emissions and global BC forcing because Russia is by far the largest Arctic state in terms of territory. Bond et al. (2004 and 2013) provide an overview of global emissions of black carbon and their forcing (Bond et al., 2004, 2013). The US Department of Agriculture estimates BC emissions from agricultural burning in Russia (USDA, 2012). McCarty et al. (2012) estimate the range of average annual BC emissions from cropland burning in Russia at $8.90 \mathrm{Gg}$, based on agricultural statistics. Cheng (2014) estimates the likely geographical distribution of Russian black carbon emission sources. 
Diesel is an important source of emissions globally, for example, the US EPA Report to Congress on Black Carbon indicates that nearly $50 \%$ of BC emissions in the United States came from mobile diesel engines in 2005 (EPA, 2012). Russia has several trends that affect its diesel consumption and emissions in the transport sector. Diesel is growing as a transportation fuel. Road traffic has grown rapidly in Russia in the past decade, linked to economic growth and growing demand for cars. The popularity of diesel light-duty vehicles has grown: many higher class or sports utility vehicles that perform well in snow rely on diesel. In Murmansk, we found that $12 \%$ of light-duty passenger vehicles used diesel, which is somewhat higher than older estimates Russia-wide. The Russian company Avtostat estimated that the share of diesel cars driving in Russia in 2012 was $4 \%$. The share of newlysold diesel cars was $6 \%$. Freight transport has also been growing in Russia. At the same time, Russia has European standards for limiting particulate emissions from on-road vehicles: currently, new or imported vehicles must be at least Euro 4. (In the European methodology, by convention, lightduty vehicles are marked with Arabic numerals while Roman numbers are used for heavy-duty vehicles (trucks and buses). Euro 4 vehicle regulations require emissions that are 20-30 times lower than vehicles with no controls (e.g., Euro 0). In the past year, two of the largest bus companies in the Murmansk Region began to upgrade their bus fleets, retiring old Euro 0 buses and replacing them with Euro IV and Euro V buses; our inventory base year (2012) predates this change.

Russia has also adopted European standards for fuel quality, which is important because emissions controls will not operate properly when diesel has high sulfur content. Russia has not introduced fuel quality standards as rapidly as its vehicle standards, so currently, three types of diesel are available on the market in Murmansk: Euro 3, 4 and 5. In 2013, Euro 5, with a maximum sulfur content of $10 \mathrm{ppm}$, accounted for $52 \%$ of Russian diesel production for the domestic market while the share of Euro 4 was $18 \%$ and Euro 3 was $26 \%$ (Novak, 2014).

Russia has no requirements for emission controls on offroad vehicles, so off-road vehicles, particularly in open-pit mines in the Murmansk Region, represent a major source of black carbon emissions. While Russia has considered adopting European standards for off-road vehicles, it has not yet done so. At the same time, as with on-road transportation, we found evidence that some off-road vehicles in Russia exceed current requirements.

Regarding rail emissions, most of Murmansk rail operates on electricity. Diesel locomotives operate in freight depots and within industrial facilities. Diesel locomotives in Murmansk do not appear to have controls. Likewise, we did not find evidence that diesel generators typically have controls, and there are no regulations requiring such controls.

We also assessed emissions from the large Murmansk fishing fleet. Despite the size of the fleet, it does not account for a large share of emissions in the Murmansk Region. Most of the large fishing vessels registered in Murmansk rarely if ever call in to the Murmansk Port, based on port registries.

By design and because of sensitivities and data availability, we did not include military consumption or consumption from commercial shipping in our analysis. The military likely represents an important source of diesel consumption; commercial shipping, on the other hand, primarily relies on heavy fuel oil, not diesel, and most of the ships quickly leave Russian territorial waters.

The impact of regulations in reducing emissions is quite clear based on our analysis in Murmansk. Without regulation of vehicles and fuel, emissions would be substantially higher. Likewise, off-road vehicles and other sources would be significantly lower if emission controls were obligatory. For example, EPA calculates the effect of emission regulations of off-road vehicles in the US and estimates that BC emissions will decrease by $92 \%$ between 2005 and 2030 as a result of emission regulations (EPA, 2012).

\section{Methodology}

Our approach to estimating BC emissions involved combining fuel consumption and activity data with emission factors, which is consistent with the literature (Bond et al., 2004; Klimont et al., 2002; EPA, 2012; EEA, 2009, 2013; Streets et al., 2004). Since measured BC emission factors from Russian diesel sources are not available, we estimated BC emissions from $\mathrm{PM}$ emissions and then applied a speciation ratio to estimate $\mathrm{BC}$ emissions. We used similar methods to estimate organic carbon (OC) emissions.

Calculations of black carbon emissions from all sources (except on-road transport can be expressed by Eq. (1) (EEA, 2009):

$$
\begin{aligned}
\mathrm{BC} \text { emisisons } & =\text { fuel }(\mathrm{kg}) \times \text { PM emission factor }\left(\mathrm{g} \mathrm{kg}^{-1}\right) \\
& \times \frac{\mathrm{BC}}{\mathrm{PM}} \text { ratio. }
\end{aligned}
$$

We applied different methodologies to different fuel combustion technologies.

The Scientific Research Institute of Automobiles and Transportation (NIIAT) developed the Russian emission models. These models are based on the COPERT 4 model with some simplifications. COPERT (COmputer Programme to calculate Emissions from Road Transport) is an emission calculator developed by EMISIA SA for the European Environment Agency (EEA).

Wherever possible, we used Russian methodologies or PM emission factors (NIIAT, 2008a, b); for example, we used both Russian and European emission factors to estimate emissions from on-road vehicles; the Russian methodologies included emission factors for the typical vehicle fleet on Russian roads. The COPERT model is the source for BC / PM ratios for on-road transport. Additional detail on our methodology can be found in Evans et al. (2012). 
Table 1. $\mathrm{PM}_{2.5}$ emission factors and $\mathrm{BC} / \mathrm{PM}$ ratios for diesel sources.

\begin{tabular}{|c|c|c|c|c|}
\hline Sector & $\mathrm{PM}_{2.5}, \mathrm{~g} \mathrm{~kg}^{-1}$ & Source & $\mathrm{BC} / \mathrm{PM}$ & Source \\
\hline \multicolumn{5}{|c|}{ Transport } \\
\hline Rail & 1.44 & EEA (2013), 1.A.3.c, Table 3.1. & 0.65 & EEA (2013), 1.A.3.c, Table 3.1. \\
\hline Other transport & 4.31 & EEA (2013), 1.A.4., Table 3-2 & 0.5 & EEA (2013), 1.A.4., Table D.1 \\
\hline \multicolumn{5}{|c|}{ Industry } \\
\hline Mining and quarrying & 3.551 & EEA (2013), 1.A. 4., Table 3-2 & 0.62 & EEA (2013), 1.A.4., Table D.2 \\
\hline Construction & 4.308 & EEA (2013), 1.A. 4., Table 3-2 & 0.62 & EEA (2013), 1.A.4., Table D.2 \\
\hline Other industry & 4.308 & Same as construction & 0.62 & EEA (2013), 1.A.4., Table D.2 \\
\hline \multicolumn{5}{|c|}{ Other sectors } \\
\hline Agriculture/forestry & 3.755 & EEA (2013), 1.A. 4., Table 3-2 & 0.57 & EEA (2013), 1.A.4., Table D.2 \\
\hline Residential & 6.0 & Data from Bond et al. (2004) & 0.66 & Data from Bond et al. (2004) \\
\hline Commercial and public services & 6.0 & Data from Bond et al. (2004) & 0.66 & Data from Bond et al. (2004) \\
\hline Fishing & 1.4 & EEA (2013), 1.A.3.d, Table 3-2 & 0.31 & EEA (2013), 1.A.3.d, Table 3-2 \\
\hline Fishing $\left(\mathrm{g} \mathrm{kWh}^{-1}\right)$ & 0.3 & EEA (2013), 1.A.3.d, Table 3-10 & 0.31 & EEA (2013), 1.A.3.d, Table 3-1 \\
\hline
\end{tabular}

For other sources, we used emission factors and speciation ratios from the EMEP/EEA Air Pollutant Emission Inventory Guidebook (Table 1). We decided to use the European Monitoring and Evaluation Programme (EMEP) data for consistency. However, US EPA has a more rigorous procedure for determination of BC / PM ratios; EMEP is currently updating its emissions factors and speciation ratios.

We collected detailed bottom up activity data from several sources, depending on the needs of the emission calculation methodology. We collected extensive primary data on road traffic in Murmansk (see Table 2 for details). The Supplement provides additional details on several of these data sets.

Regarding off-road vehicles, we used statistical data as well as public information from annual corporate reports and other public sources. For power generators, we received a detailed list of the largest off-grid diesel generators in the Murmansk Region, and supplemented this with analysis comparing population centers with the power grid and statistics on fuel use. We also relied on regional statistical data about non-transport diesel consumption by different sectors of the economy. Regarding the marine fleet, we used public data from Russian ship registries and port calls. We only counted the fraction of ship emissions corresponding to the time they spent in Russian territorial waters.

\section{Analysis of fuel consumption in the Murmansk Region}

We reviewed the official statistical data on diesel consumption in the Murmansk Region, which include annual summary data on consumption and stock changes by broad categories, and a breakdown of enterprise consumption for transport and non-transport needs organized by economic activity. The summary data from the Murmansk Statistical Office and the more detailed data from various sectors appear to have some methodological differences. The summary data appear to include different categories across different years, causing major swings in the total reported fuel use. For example, the Murmansk Statistical Office reports diesel consumption at $391900 \mathrm{t}$ in 2012 while the total diesel consumption was $599120 \mathrm{t}$ in 2011. The official statistical data also include bunker fuel for marine transport. The Murmansk Statistical Office reports that fishing ships consumed $68300 \mathrm{t}$. Our bottom-up calculations show that fishing ships consumed only $3000 \mathrm{t}$ while in Russian territorial waters.

Because of these factors, we also estimated consumption by sector using bottom-up calculations where possible. Except in the case of mines, statistical data were significantly different from our bottom-up estimates.

In Table 3 below, we provide our consolidated estimate of diesel use in the Murmansk Region in 2012.

Table S1 in the Supplement provides additional details on our bottom-up fuel calculation for on-road transport; Table S9 highlights these calculations for mines, and Tables S16 and S20 estimate fuel use for fishing and diesel generators, respectively.

\section{On-road transport in Murmansk}

\subsection{Activity data}

On-road transportation is one of the largest sources of black carbon emissions in the region; it also appears to be the largest diesel source in Russia as a whole. We conducted detailed surveys and data collection related to the vehicle fleet, traffic and vehicle use in assessing on-road transport emissions. Russia does not have detailed, published data on road traffic by vehicle type and class, and most Russian trans- 
Table 2. Main data sources on vehicle fleet and activity.

\begin{tabular}{|c|c|c|}
\hline Type of Data & Description & Notes \\
\hline Vehicle fleet & $\begin{array}{l}\text { Basic registry information on each vehi- } \\
\text { cle registered in the Murmansk Region } \\
\text { from Avtostat }\end{array}$ & $\begin{array}{l}\text { We categorized the vehicles by make, model and age, } \\
\text { and then assessed diesel use and ecological class based } \\
\text { on manufacturer data of the models. }\end{array}$ \\
\hline Passenger cars in use & $\begin{array}{l}\text { Parking lot surveys at several locations } \\
\text { throughout central and suburban Mur- } \\
\text { mansk City }\end{array}$ & $\begin{array}{l}\text { The surveys provided data on the vehicle models actu- } \\
\text { ally in use. We assessed the models for age and ecolog- } \\
\text { ical class as we did with the Avtostat data. }\end{array}$ \\
\hline $\begin{array}{l}\text { Passenger cars in use } \\
\text { and odometer readings }\end{array}$ & $\begin{array}{l}\text { Database of vehicle inspection station } \\
\text { on MSTU campus }\end{array}$ & $\begin{array}{l}\text { This provided additional data on vehicles on the roads } \\
\text { as well as their age and odometer readings (average km } \\
\text { traveled per year). }\end{array}$ \\
\hline Traffic intensity & Video surveys & $\begin{array}{l}\text { MSTU conducted video surveys to count total traffic by } \\
\text { vehicle type (cars, light-duty vehicles, buses and trucks) } \\
\text { on different road categories in both central and suburban } \\
\text { Murmansk City. Surveys covered different hours of the } \\
\text { day. }\end{array}$ \\
\hline $\begin{array}{l}\text { Road categories and } \\
\text { length }\end{array}$ & $\begin{array}{l}\text { Municipal data on road categories and } \\
\text { lengths }\end{array}$ & $\begin{array}{l}\text { We used these data to help select road segments for } \\
\text { the video surveys and to correlate the video survey data } \\
\text { with the rest of the city roads by category. }\end{array}$ \\
\hline Road speed and grade & GPS logger data & $\begin{array}{l}\text { We used specialized GPS data loggers to track road } \\
\text { speed by road type at different times of day. The log- } \\
\text { gers also provided data on road grade. In addition, we } \\
\text { used data from the Yandex traffic service to assess road } \\
\text { speed. }\end{array}$ \\
\hline
\end{tabular}

Table 3. Estimated diesel consumption by sector in the Murmansk Region, 2012.

\begin{tabular}{lr}
\hline Activity & Diesel use $(\mathrm{t})$ \\
\hline On-road transport* & 65100 \\
Mines & 139000 \\
Locomotives & 21200 \\
Construction & 4100 \\
Agriculture & 1300 \\
Diesel generators, including: & 8800 \\
$\quad$ Small generators for commerce and services* & 7100 \\
Off-grid generators* & 1700 \\
Fishing (in Russian territorial waters), including: & 3000 \\
$\quad$ Large and medium vessels* & 2500 \\
$\quad$ Small boats* & 500 \\
Total & 242500 \\
\hline
\end{tabular}

* bottom up calculations. The other numbers come from regional statistics. This table does not consider marine shipping and military fuel use.

portation experts believe that vehicle registries include some vehicles that are not used or used only lightly. As a result, we used multiple sources to study on-road transport in Murmansk and the region. Table 3 highlights our surveys and data sources.
Murmansk City had 16400 diesel vehicles registered in 2012, while in the Murmansk Region, there are 45600 diesel vehicles registered. The registry showed that $45 \%$ of all cars and other light duty vehicles (LDVs), $62 \%$ of trucks and $75 \%$ of buses are likely Euro 0, based on their age. Passenger cars in general are much newer and cleaner than buses or trucks. Based on parking lot surveys of 2235 cars, we found that on average, $12 \%$ of the passenger cars in Murmansk run on diesel, which is higher than the Russian average. The average age of diesel passenger cars in Murmansk City is 5.6 years.

We relied on several data sources to assess average annual mileage for passenger cars; NIIAT provided estimates for average annual mileage of other vehicle types. We used our video survey data to estimate average annual daily traffic (AADT), and then multiplied this by the kilometers of road by road category to estimate vehicle-kilometers traveled (VKT) in the city.

We also adjusted the regional registry using the ratio between registered and observed vehicles obtained in Murmansk City. We estimated there were 14500 diesel cars, 2600 LDVs, 3900 trucks and 260 buses used in the region.

\subsection{Emissions estimates}

We used several methodologies to estimate emissions in the city and the region. We reviewed several Russian method- 
ologies, including two prepared by the Scientific Research Institute for Automobile Transport (NIIAT, 2008a, b), as well as the European Environmental Agency methodology, COPERT (Emisia, 2011). The NIIAT methodologies use Russianspecific emission factors for $\mathrm{PM}_{2.5}$ based on the average fleet of vehicles of each ecological class on Russian roads. At the same time, the Russian methodologies have much lower emission factors for cold starts in small vehicles than other international methodologies. While some Russian drivers warm their cars before they begin driving, which reduces emissions from cold starts, without survey data measuring cold start emissions more precisely, we decided it would be more consistent with inventories elsewhere to use European emission factors for cold starts, particularly given the cold Russian climate.

First, we used the COPERT model to calculate BC emissions using default European emission factors for various types and Euro class vehicles. Then we substituted the default emission factors with specific Russian emission factors to reflect the specifics of the Russian fleet.

Figure 1 summarizes our emission estimates by vehicle type using COPERT with Russian emission factors.

Figure 2 shows the percentage split of emissions between Euro classes for each vehicle type. The majority of emissions come from Euro 0 vehicles, in particular Euro 0 trucks. Cold starts also play an important role. Among passenger cars and other light-duty vehicles, $37 \%$ of total black carbon emissions come from cold starts.

We also cross-checked the results using the NIIAT methodology with Russian emissions factors. Finally, instead of using the vehicle count from video surveys, we used COPERT to calculated emissions from the entire registered vehicle fleet in Murmansk City. This allows us to show that using the registry data significantly overestimates the emissions in the city.

Table 4 presents a summary of total vehicle emissions in the city using each of the methodologies. Table S5 provides additional details on emission calculations

The results in Table 4 clearly show that one should be very careful in using registry data for emission estimates. The difference between estimated emissions from the observed fleet is 4.7 times smaller than the potential emissions from the fleet of all registered vehicles, as the Russian vehicle registries likely contain many vehicles not actually in use.

We also calculated total road transport emissions in the Murmansk Region using the NIIAT universal methodology (NIIAT, 2008). This methodology is simpler and designed for use with limited vehicle activity data; estimating emissions at the regional level provides a snapshot of the relative weight of different black carbon emission sources in the region. At the same time, we recognize that this is an approximate estimate and may, for example, underestimate emissions from cold starts and overestimate driving by older, Euro 0 vehicles. We found total road transport emissions in the region to

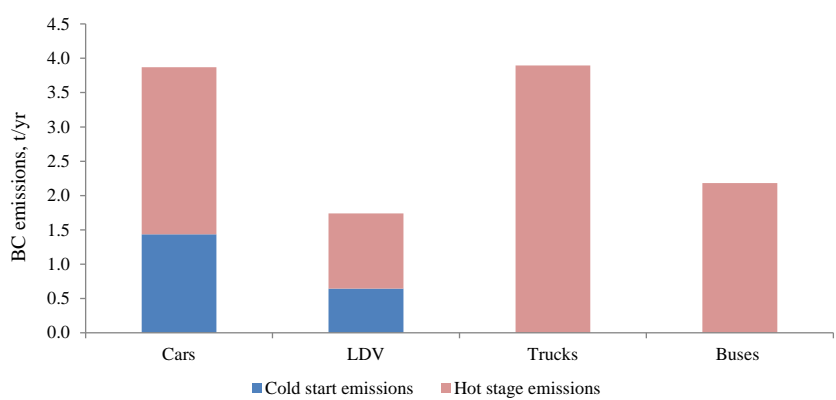

Figure 1. Cold start and hot stage BC emissions in Murmansk City by vehicle type $(\mathrm{t})$.

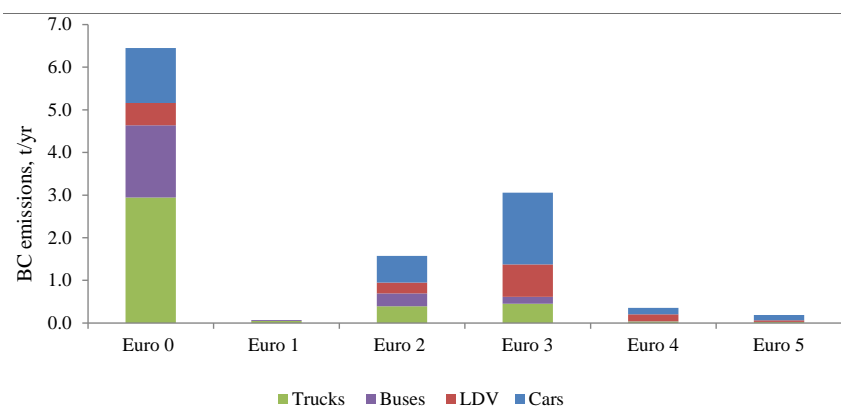

Figure 2. BC emissions in Murmansk City by ecological class and vehicle type $(\mathrm{t})$.

be $98.9 \mathrm{t}$ of $\mathrm{PM}_{2.5}$ and $53.7 \mathrm{t}$ of BC (Table S6 in the Supplement).

\section{Off-road transport}

\subsection{Mines}

The mining industry is an economic backbone in the Murmansk Region. It accounts for about $40 \%$ of the region's industrial output. The region produces $100 \%$ of Russian apatite, nepheline and brazilite, $45 \%$ of nickel and $11 \%$ of iron ore.

The mining industry is by far the largest industrial consumer of diesel in the Murmansk Region. According to official statistical data, mining companies in the region consumed $139000 \mathrm{t}$ of diesel in 2012. The largest mines in the Murmansk Region are Apatite Joint Stock Company, Kovdorskiy GOK, Olenegorskiy GOK and Kolskaya GMK (Table S9 in the Supplement).

Most of the companies operate open-pit mines; large, haul trucks and mining equipment are the major diesel consumers. The Belarusian automaker BELAZ supplies the majority of the largest trucks, i.e., those with a payload capacity over 100 t. Most BELAZ trucks are equipped with Cummins and MTU engines. Table S10 shows the technical characteristics of BELAZ trucks. Recently, mining enterprises have been 
Table 4. BC emissions in Murmansk City from on-road transport, different methodologies, $\mathrm{tyr}^{-1}$.

\begin{tabular}{lrrrr}
\hline & $\begin{array}{r}\text { COPERT with NIIAT EFs } \\
\text { (based on surveys) }\end{array}$ & $\begin{array}{r}\text { NIIAT universal } \\
\text { (based on surveys) }\end{array}$ & $\begin{array}{r}\text { NIIAT for large cities } \\
\text { (based on surveys) }\end{array}$ & $\begin{array}{r}\text { COPERT with NIIAT EFs } \\
\text { (uncorrected registry) }\end{array}$ \\
\hline Cars & 3.9 & 2.5 & 3.0 & 6.1 \\
LDV & 1.7 & 1.1 & 1.1 & 14.4 \\
Trucks & 3.9 & 3.9 & 2.7 & 28.7 \\
Buses & 2.2 & 2.2 & 1.0 & 5.7 \\
Total & 11.7 & 9.7 & 7.8 & 54.9 \\
\hline
\end{tabular}

purchasing more foreign-made trucks, and mines have been gradually replacing the older BELAZ models with Caterpillar and Komatsu trucks. Nevertheless, BELAZ trucks still constitute $70 \%$ of the Russian mining fleet (Petrovich et al., 2013).

Mining operations continue nonstop and on average each truck operates well over $6300 \mathrm{~h}$ per year (Mining Magazine, 2007). There is no official data on the number of mining trucks in the Murmansk Region. Using information from individual mines, we estimated that there are no less than 250 mining trucks. In addition to dump trucks, mines operate a wide range of machinery, including excavators, bulldozers, loaders, drilling equipment and other machinery. On average, excavators and bulldozers operate 7270 and $6660 \mathrm{~h}$ per year, respectively. The mines also use supplementary, smaller on-road trucks with payloads from 13 to $45 \mathrm{t}$.

Statistical data in the region indicate that mining companies consumed $139013 \mathrm{t}$ of diesel fuel in 2012. We also cross-checked this data through bottom-up estimates of fuel use in the largest mines. The results of cross-checking showed that the statistical data and bottom-up calculations match closely (with a difference of less than $1 \%$ ).

Russia does not have emission regulations for off-road vehicles but often uses foreign-made, off-road vehicles and equipment. Thus, we have used both US EPA and European Environment Agency information about emission requirements for off-road vehicles. Table S7 shows PM emission requirements in the US and Europe.

The extent of controls is one of the important uncertainties regarding emission estimates from the mining sector. Since there are no emission control requirements, the mining vehicles may not meet even Tier 1 requirements. Based on information from Cummins, $88 \%$ of the large, Cumminspowered, BELAZ mining trucks have no controls on their engine exhaust and the remaining $12 \%$ meet EPA Tier 1 requirements (R. Mueller, personal communication, 2014). A smaller population of Caterpillar and Komatsu trucks meets Tier 1 or Tier 2 requirements (Table S11).

The $\mathrm{PM}_{2.5}$ emission factor for off-road, industrial mobile sources and machinery without emission controls is $3.551 \mathrm{~g} \mathrm{~kg}^{-1}$ fuel and the emission factor for equipment with some controls is $0.967 \mathrm{~g} \mathrm{~kg}^{-1}$ fuel. The $\mathrm{BC} / \mathrm{PM}$ ratio is 0.62 (EEA, 2013).
We estimated that $\mathrm{PM}_{2.5}$ emissions in the mining industry in the Murmansk Region are $450.5 \mathrm{t}$ per year. Total BC and $\mathrm{OC}$ emissions in the mining industry in the Murmansk Region is estimated to be 279.3 and $83.8 \mathrm{t}$ per year, respectively.

\subsection{Locomotives}

Diesel locomotives are only in limited use in the Murmansk Region because all the main railroads are electrified. According to data from the Murmansk statistical office, diesel locomotives at the Murmansk branch of Russian Railways consumed $21200 \mathrm{t}$ of diesel in 2012 (GSK, 2012).

Diesel locomotives in Russia do not have any emission controls. Some of the locomotives in the Murmansk Region are more than 30 years old. Since we have limited information on the activity of the small line haul and switch locomotives, the only way to estimate $\mathrm{BC}$ emissions is to use the fuel consumption method.

The emission factor for $\mathrm{PM}_{2.5}$ of switch locomotives is $1.44 \mathrm{~g} \mathrm{~kg}^{-1}$ of fuel. The speciation ratio for $\mathrm{BC} / \mathrm{PM}_{2.5}$ for locomotives is 0.65 (EEA, 2013). Thus, locomotives in the Murmansk Region emitted $30.5 \mathrm{t}$ of $\mathrm{PM}_{2.5}$, including $19.8 \mathrm{t}$ of $\mathrm{BC}$ and $4.0 \mathrm{t}$ of $\mathrm{OC}$.

\subsection{Construction and road management}

This sector includes building construction and road management. According to official statistics, the building construction industry used $3205 \mathrm{t}$ of diesel. Road management companies used $865 \mathrm{t}$ of diesel fuel for off-road vehicles, machinery and equipment.

Building construction is stagnant in the Murmansk Region. The region's population is declining and the formerly powerful construction industry is deteriorating. The vast majority of equipment in the construction industry is very old. There are over 1800 pieces of equipment and more than $50 \%$ of equipment and machinery need replacement (see Table S12 for details). We assume that $90 \%$ of equipment has no emission controls and $10 \%$ has some controls.

We used EMEP-EEA emission factors (EEA, 2013) for off-road vehicles in the construction industry, e.g. $4.038 \mathrm{~g} \mathrm{PM}_{2.5} \mathrm{~kg}^{-1}$ fuel for vehicles without controls and $0.967 \mathrm{~g} \mathrm{~kg}^{-1}$ fuel for equipment with some controls. The 
$\mathrm{BC}$ / PM ratio for construction is 0.62 . Hence, off-road building construction vehicles in the Murmansk Region emitted $12.7 \mathrm{t}$ of $\mathrm{PM}_{2.5}, 7.9 \mathrm{t}$ of $\mathrm{BC}$ and $1.6 \mathrm{t}$ of OC.

The road management sector includes minor road reconstruction and snow removal. Murmansk City is located on the shore of the Barents Sea and the level of precipitation is quite high. On average, there is snow on the ground 180-200 days per year. The snow removal fleet was significantly updated recently with Russian-made, multifunctional vehicles and off-road vehicles, including new tractors and graders, which do not have any emission controls.

Similarly to construction, we have to exclude on-road vehicles from the emission calculations. The emission factor for off-road machinery without emission controls in this sector is $3.551 \mathrm{~g} \mathrm{PM}_{2.5} \mathrm{~kg}^{-1}$ fuel and the $\mathrm{BC} / \mathrm{PM}$ ratio is 0.62 (EEA, 2013). Off-road vehicles in this sector in the Murmansk Region emitted $2.8 \mathrm{t}$ of $\mathrm{PM}_{2.5}, 1.7 \mathrm{t} \mathrm{BC}$ and $0.4 \mathrm{t} \mathrm{OC}$.

Total emissions from off-road vehicles and equipment in building construction and road management sector were 15.6 $\mathrm{t}$ of $\mathrm{PM}_{2.5}, 9.7 \mathrm{t} \mathrm{BC}$ and $2.9 \mathrm{t} \mathrm{OC}$.

\subsection{Agriculture}

Over $90 \%$ of the Murmansk Region lies above the Arctic Circle and agriculture is not well developed. The agricultural machinery in the region is Russian-made with a small fraction of foreign-made equipment; $62 \%$ of agricultural machinery is older than 10 years.

According to regional statistics agricultural enterprises in the Murmansk Region consumed $1344 \mathrm{t}$ of diesel in 2012. The emission factor for agricultural equipment without emission controls is $3.755 \mathrm{~g} \mathrm{PM}_{2.5} \mathrm{~kg}^{-1}$ fuel assuming no controls and the BC / PM ratio is 0.57 (EEA, 2013). We thus estimated total PM emissions from agricultural equipment in the Murmansk Region at 5.0 t of $\mathrm{PM}_{2.5}, 2.9 \mathrm{t}$ of $\mathrm{BC}$ and $0.9 \mathrm{t}$ of OC.

\section{Fishing and marine transport}

The Murmansk Port is the largest Russian port in the Arctic. We analyzed emissions from fishing vessels, various cargo ships, tankers, passenger ships and support ships.

The activity data for ships are based on the Russian Information System on State Port Control (Murmansk Port, 2014). We obtained information about diesel engine capacity from the Russian Maritime Register of Shipping (The Russian Maritime Register of Shipping, 2014). The Murmansk Port is located 22 nautical miles from the open sea and we analyzed emissions from the port to the edge of Russian territorial waters (further 12 miles out to sea). We assume that it takes $7 \mathrm{~h}$ to get from the port to the edge of the territorial waters.

Fishing is an important part of Murmansk's economy. The fishing industry in the Murmansk Region provides $16 \%$ of
Russia's total fish catch. Fishing companies in the Murmansk Region operate mainly in nearby international waters $(62 \%$ of the catch). Only a quarter of the catch occurs in Russian 12 mile territorial waters (Committee for the Fishery Complex of the Murmansk Region, 2013).

The fishing fleet in the Murmansk Region consists of 226 sea vessels (2012) or $76 \%$ of all civilian vessels in the Russian Arctic. The average age of the vessels is 26 years old (see Tables S13-S14 for details). In addition to large and medium ocean-going vessels, there are around 100 small vessels for off-shore fishing. All this fish catch from these small vessels was brought into ports in the Murmansk Region.

It is very difficult to estimate the fuel consumption in the fishing industry. The official statistics show that fishing companies consumed $68289 \mathrm{t}$ of diesel in 2012. However, there are several challenges with this data. First, Russian fishing vessels buy and consume the majority of their fuel outside of Russia and Russian territorial waters. Second, companies may have an incentive to over-report fuel consumption, possibly to increase their reported costs. As a result, we provide a bottom-up estimate of fuel consumption in the Russian waters for fishing.

We calculated fuel use and BC emissions in Murmansk based on the port calls for large and medium fishing vessels and, for small vessels, our estimates draw on the reported number of small fishing boats and local expert judgment on their operations.

Large and medium fishing vessels called into the Murmansk Port 1713 times in 2012, according to the Russian Information System on State Port Control (Murmansk Port, 2014).

Using the information about the installed power capacity, engine load and time traveled, we calculated PM emissions within Russian territorial waters from fishing vessels. PM emission factor is $0.3 \mathrm{~g} \mathrm{kWh}^{-1}$ and the $\mathrm{BC} / \mathrm{PM}$ ratio is 0.31 (EEA, 2013). We assumed that all fishing vessels use diesel (According to the EEA emissions inventory guidebook, only $3.8 \%$ of fishing vessels use both diesel and bunker fuel oil). We estimate that these large and medium fishing vessels emitted $3.7 \mathrm{t}$ of PM and $1.1 \mathrm{t}$ of BC.

In addition, there are about 100 small fishing ships. Detailed registries and other data about installed engine capacity and hours of operation are not available. In consultation with local fishing and marine experts, we assumed that the average engine capacity is $50 \mathrm{~kW}$, engine load is $60 \%$, the boats sail $800 \mathrm{~h}$ per year. The total $\mathrm{BC}$ emissions by small fishing boats were $0.88 \mathrm{t}$ per year.

Total emissions from all types of fishing vessels in the Murmansk Region were $6.4 \mathrm{t}$ of PM and $2.0 \mathrm{t}$ of BC.

We also prepared bottom-up estimates of fuel use, based on information about rated engine power, hours of operation and specific fuel consumption ( $\mathrm{g}$ fuel $\mathrm{kWh}^{-1}$ ). The specific fuel consumption is $203 \mathrm{~g}$ diesel $\mathrm{kWh}^{-1}$ (EEA, 2013). The fuel consumption by large and medium ships during their travel within Russian territorial waters is $2481 \mathrm{t}$ per year (Ta- 
Table 5. Number of port calls and emissions from ships. "n/a" means not available.

\begin{tabular}{lrrrr}
\hline Type & $\begin{array}{r}\text { Number of } \\
\text { port calls }\end{array}$ & $\begin{array}{r}\text { PM emissions, } \\
\mathrm{t}\end{array}$ & $\begin{array}{r}\text { BC emissions, } \\
\mathrm{t}\end{array}$ & $\begin{array}{r}\text { OC emissions, } \\
\mathrm{t}\end{array}$ \\
\hline Fishing & 1713 & 3.7 & 1.1 & 0.2 \\
Small fishing boats & $\mathrm{n} / \mathrm{a}$ & 0.7 & 0.2 & 0.0 \\
Cargo, all & 604 & 3.1 & 1.0 & 0.2 \\
Tankers & 420 & 2.7 & 0.8 & 0.2 \\
Support & 203 & 2.2 & 0.7 & 0.1 \\
Passenger & 83 & 1.0 & 0.3 & 0.1 \\
Total & 3042 & 13.4 & 4.2 & 0.8 \\
\hline
\end{tabular}

Source: Murmansk Port, 2014

ble S16 provides additional details). The fuel consumption by small boats is $487 \mathrm{t} \mathrm{yr}^{-1}$.

Other categories of ships calling into the Murmansk Port include various cargo ships (general cargo, bulk and container ships), tankers, passenger ships and support ships (tugs, research ships and other vessels). We used the same methodology for emission calculations as for fishing ships.

We assumed that passenger and support ships use diesel. However, cargo ships and tankers use heavy marine oil and diesel. We assumed that these ships use diesel only for $1 \mathrm{~h}$ per call while in the port. Table 5 shows the number of port calls and emissions from ships in Russian territorial waters.

The Supplement provides additional details about the ships in the Murmansk Port.

\section{Diesel generators}

We found several types of diesel generators and heaters in the Murmansk Region. The largest category in terms of fuel use and emissions is generators and heaters that small market shops and service providers operate in settled areas. The next largest category includes off-grid generators that operate for a large portion of the year, typically up to $12 \mathrm{~h}$ a day.

We found the least data for the very small generators and heaters used in commerce and services - the government does not appear to regulate or keep statistics on these small generators. The data quality regarding diesel generators is very low and the uncertainty is very high. In total, government statistics show that non-transport diesel use from these sectors was $7100 \mathrm{t}$ in 2012. We also verified the existence of such generators by looking at the number of dealers selling diesel generators in Murmansk. With the emission factor for diesel generators of $6.0 \mathrm{~g} \mathrm{PM} \mathrm{kg}^{-1}$ fuel and $\mathrm{BC} / \mathrm{PM}$ ratio of 0.66 for this category (Bond et al, 2004), we assumed that such small generators and heaters emitted $42.6 \mathrm{t}$ of PM, $28.1 \mathrm{t}$ of BC and 5.6t OC in 2012.

Regarding off-grid generators, it is important to note that the majority of the Murmansk Region's urban and rural energy consumers receive their power from the Kola Power Grid. Several dozen settlements in the region lack access to centralized electricity supply, due to their remote locations; instead they rely on diesel generators (Minin, 2012). The largest villages without centralized electricity supply receive diesel subsidies. Table S20 shows the capacity of these subsidized diesel generators and their annual fuel consumption. In total, according to the Development Strategy for Energy Savings in the Murmansk Region, there were 80 settlements without centralized electricity supply in 2009. About 150 village diesel generators with a total capacity of $3.8 \mathrm{MW}$ provided electricity to these settlements (Government of the Murmansk Region, 2009). We used information about fuel consumption and power capacity of generators with subsidized fuel and proportionally calculated the possible total fuel consumption by this category of generators. Using bottom-up calculations, we estimated that off-grid generators consume $1700 \mathrm{t}$ of diesel per year. We further estimate that off-grid generators in the Murmansk Region emitted 10.2 $\mathrm{t}$ of PM, $6.7 \mathrm{t}$ of $\mathrm{BC}$ and $1.3 \mathrm{t}$ of OC.

The total emissions from diesel generators in the region estimated to be $52.8 \mathrm{t}$ of PM, $34.8 \mathrm{t}$ of $\mathrm{BC}$ and $7.0 \mathrm{t}$ of OC.

\section{Uncertainty analysis}

Uncertainties exist in emission factors, activity data and emission controls; we used multiple approaches to estimate and reduce uncertainties of the BC emissions inventory. This could help us validate the inventory estimates, choose appropriate methodological approaches and improve the accuracy of the results (IPCC, 2006). This could also help peer reviewers understand the reliability of our inventory estimates. We used five methods to assess and minimize uncertainties (EEA, 2013; IPCC, 2006, 2000), including:

- Multiple approaches to collecting and validating activity data;

- Literature and other documented data for cross-checks;

- Cross-checks of bottom-up activity data and fuel allocation;

- Error propagation; and 
- Expert judgment.

We derived aggregate uncertainties of the emissions inventory based on the error propagation method. We combined uncertainties of emission factor and activity data by source category, and then combined uncertainties by source category to estimate overall uncertainty of the inventory (IPCC, 2006). For emission factors, we use uncertainties from Bond inventory (Bond, 2004) (Table S18). Uncertainties in activity data are primarily assessed based on expert judgment.

The relative uncertainty in the emission for each activity and fuel combination is calculated as the square root of the sum of squares of the relative uncertainties in both activity data and the emission factors. The absolute uncertainty in the emission of each activity and fuel combination is derived by multiplying the relative uncertainty with the emission value. The relative uncertainty in $\mathrm{BC}$ emissions in Murmansk region is from -50 to $+165 \%$. For major sources of $\mathrm{BC}$ emissions, we also used cross-checks to assess sectoral uncertainties. For on-road emissions we found that there is a $19 \%$ difference between estimated emissions from COPERT with NIIAT emission factors and COPERT with COPERT emission factors.

The largest uncertainty in mining lies in assumptions on emission controls and fuel use (Table S19 and S20). Uncertainty about Tier distribution could significantly change the results of our emissions calculation given the significant fuel consumption in the mining industry.

\section{Simple estimate of Russian diesel emissions}

According to IEA data, Russia consumed 23.3 million t of diesel in 2010 (IEA, 2012). On-road transport accounted for 12.5 million t of diesel, while agriculture and forestry consumed an additional 2.8 million $\mathrm{t}$ and industry 2.6 million $\mathrm{t}$ of diesel. All other sectors combined consumed an additional 2.9 million $t$ of fuel (Table 6).

Since on-road transport is the largest consumer of diesel, we conducted a more detailed analysis of $\mathrm{BC}$ emissions by on-road vehicles. We simply applied fuel-based emission factors to all other sectors.

According to the Federal State Statistics Service of the Russian Federation, there were 5181200 diesel vehicles in Russia in 2010. NIIAT conducted bottom-up calculations of fuel consumption by on-road vehicles in Russia and estimated it at 17.3 million $t$ per year. We decided to use the IEA data for consistency but used NIIAT estimates for the distribution of diesel consumption by types of vehicles. Table S21 shows fuel consumption by different types of vehicles and Table S25 shows diesel fleet distribution by ecological class based on NIIAT estimates.

We calculated PM emissions by using NIIAT fuel-based emissions factors (NIIAT, 2008). The PM emission factor is $4 \mathrm{~g} \mathrm{~kg}^{-1}$ fuel for Euro 0 vehicles, 1.1 for Euro 1 and Euro 2 vehicles and $0.8 \mathrm{~g} \mathrm{~kg}^{-1}$ fuel for higher ecological classes. We
Table 6. Diesel consumption in Russia, 2010.

\begin{tabular}{|c|c|}
\hline Sector & Diesel, thousand $\mathrm{t}$ \\
\hline \multicolumn{2}{|l|}{ Transport } \\
\hline Road transport & 12508 \\
\hline Rail & 1444 \\
\hline Other transport & 1051 \\
\hline \multicolumn{2}{|l|}{ Industry } \\
\hline Mining and quarrying & 1152 \\
\hline Construction & 631 \\
\hline other industry & 765 \\
\hline \multicolumn{2}{|l|}{ Other sectors } \\
\hline Agriculture/forestry & 2829 \\
\hline Residential & 1357 \\
\hline Commercial and public services & 1165 \\
\hline Fishing & 351 \\
\hline Total & 23253 \\
\hline
\end{tabular}

Source: IEA, 2012.

estimated total PM emissions from on-road diesel vehicles in Russia in 2010 at $31001 \mathrm{t}$. We applied the BC / PM ratios to determine $\mathrm{BC}$ emissions (EEA, 2013). Table 7 shows the results of the $\mathrm{BC}$ emissions calculations from on-road diesel vehicles in Russia in 2010.

We estimated total BC emissions from on-road diesel vehicles in Russia at $16670 \mathrm{t}$ in 2010. The vast majority of BC emissions $(62 \%)$ came from Euro 0 trucks.

NIIAT fuel-based emission factors are low compared to international practice. For example, Bond et al. (2004) used fuel-based emission factor for the former Soviet Union region at $4.4 \mathrm{~g} \mathrm{PM} \mathrm{kg} \mathrm{fuel}{ }^{-1}$.

As a result, we cross-checked our calculations with the EEA methodology using bulk emissions factors (EEA, 2013). EEA bulk emission factors $\left(\mathrm{g} \mathrm{kg}^{-1}\right.$ fuel) for former Soviet Union countries are as follows: 4.95 for cars, 4.67 for LCV, 2.64 for heavy-duty trucks and 2.15 for buses. The total emissions from on-road transport were $33404 \mathrm{t}$ of PM, $19892 t$ of BC and $5968 t$ of OC. The difference in BC calculations using NIIAT and EEA approaches is $16 \%$; we decided to use the EEA approach in our inventory.

As we mentioned above, the choice of BC / PM ratios can change the results of emission calculations. For example, if we use the EPA speciation ratio (0.74) for on-road transport, $\mathrm{BC}$ emissions in Russia would be $24719 \mathrm{t}$, or $24 \%$ higher.

These results are similar to those presented in the EPA Report to Congress on Black Carbon (EPA, 2012). According to EPA estimates, $\mathrm{BC}$ emissions from transport (including aircrafts and marine shipping) in Russia were $32 \mathrm{Gg}$ in 2000.

The largest sources of diesel BC emissions in Russia in 2010 were on-road transport (43\%), agriculture and forestry $(13 \%)$ and residential sources $(12 \%)$. 
Table 7. BC emissions from on-road diesel vehicles in Russia in 2010 (t) (based on NIIAT methodology).

\begin{tabular}{lrrrrr}
\hline & Euro 0 & Euro 1 & Euro 2 & Euro 3+ & Total \\
\hline Cars & 533 & 8 & 82 & 138 & 762 \\
Trucks & 10347 & 653 & 1451 & 1278 & 13728 \\
Buses & 1451 & 156 & 324 & 251 & 2182 \\
Total & 12331 & 817 & 1857 & 1668 & 16672 \\
\hline
\end{tabular}

Table 8. $\mathrm{PM}_{2.5}$, BC and $\mathrm{OC}$ emissions from diesel sources in Russia, $2010(\mathrm{t})$.

\begin{tabular}{|c|c|c|c|}
\hline Sector & $\mathrm{PM}_{2.5}$ & $\mathrm{BC}$ & OC \\
\hline \multicolumn{4}{|c|}{ Transport } \\
\hline On-road & 33404 & 19892 & 5968 \\
\hline Rail & 2079 & 1352 & 270 \\
\hline Other transport & 4530 & 2265 & 680 \\
\hline \multicolumn{4}{|c|}{ Industry } \\
\hline Mining and quarrying & 4091 & 2536 & 761 \\
\hline Construction & 2718 & 1685 & 506 \\
\hline Other industry & 3296 & 2043 & 613 \\
\hline \multicolumn{4}{|c|}{ Other sectors } \\
\hline Agriculture/forestry & 10623 & 6055 & 1817 \\
\hline Residential & 8142 & 5374 & 1075 \\
\hline Commercial and public services & 6990 & 4613 & 923 \\
\hline Fishing & 491 & 152 & 30 \\
\hline Total & 76364 & 45967 & 12641 \\
\hline
\end{tabular}

Table 8 shows the results of emission calculations from all diesel sources.

\section{Conclusions}

We conducted a detailed, bottom-up assessment of emissions from diesel combustion in the Murmansk Region, based on surveys of vehicles, traffic and data collection regarding other significant sources (see Table 9).

We also conducted an initial estimate of Russian emissions form diesel combustion. In both Murmansk and Russia, on-road transportation is a large source of BC emissions. Within this category, Euro 0 trucks make up the vast majority of emissions. This reflects the fact that Russia now has requirements for emission controls on new vehicles, resulting in comparatively low emissions from cars and most new trucks and buses. We also found that many registered older vehicles, are driven infrequently based on parking lot and traffic video surveys, which is consistent with the literature. Surprisingly, we found that regional statistics on fuel use for on-road transportation indicate significantly lower consumption than our bottom-up estimates of fuel use in this category.
Table 9. $\mathrm{PM}_{2.5}, \mathrm{BC}$ and $\mathrm{OC}$ emissions in the Murmansk Region, $2012(\mathrm{t})$.

\begin{tabular}{lrrr}
\hline Activity & $\mathrm{PM}_{2.5}$ & $\mathrm{BC}$ & $\mathrm{OC}$ \\
\hline On-road transport in the & 98.9 & 53.7 & 36.2 \\
Murmansk Region & & & \\
Mines & 450.5 & 279.3 & 83.8 \\
Locomotives & 30.5 & 19.8 & 4.0 \\
Construction & 15.6 & 9.7 & 2.9 \\
Agriculture & 5.0 & 2.9 & 0.9 \\
Diesel generators & 52.8 & 34.8 & 7.0 \\
Ships (in Russian waters) & 13.4 & 4.2 & 0.8 \\
Total & 666.7 & 404.4 & 135.5 \\
\hline
\end{tabular}

In the Murmansk Region, the largest category of emissions is off-road vehicles, in particular mining (69\%). In Russia as a whole, agriculture represents the second largest diesel BC source. In both of these cases, the high emissions are linked to the absence of control technologies and the lack of emission standards for off-road vehicles. Off-road vehicles represent an important opportunity for reducing emissions, for example, with emission standards for new vehicles and engines.

\section{The Supplement related to this article is available online at doi:10.5194/acp-15-8349-2015-supplement.}

Acknowledgements. The authors are grateful for research support provided by the US Environmental Protection Agency, Office of International and Tribal Affairs (grant no. X4-83527901) and the US Department of State. Battelle Memorial Institute operates the Pacific Northwest National Laboratory for the US Department of Energy under contract DE-AC05-76RL01831. We thank the members of the Technical Steering Group for their helpful comments and suggestions. The views and opinions expressed in this paper are those of the authors alone.

Edited by: M. C. Facchini

\section{References}

Bond, T. C. and Sun, H.: Can Reducing Black Carbon Emissions Counteract Global Warming?, Environ. Sci. Technol., 39, 59215926, doi:10.1021/es0480421, 2005.

Bond, T. C., Streets, D. G., Yarber, K. F., Nelson, S. M., Woo, J.-H., and Klimont, Z:: A technology-based global inventory of black and organic carbon emissions from combustion, J. Geophys. Res.-Atmos., 109, D14203, doi:10.1029/2003jd003697, 2004.

Bond, T. C., Doherty, S. J., Fahey, D. W., Forster, P. M., Berntsen, T., DeAngelo, B. J., Flanner, M. G., Ghan, S., Kärcher, B., Koch, D., Kinne, S., Kondo, Y., Quinn, P. K., Sarofim, M. C., 
Schultz, M. G., Schulz, M., Venkataraman, C., Zhang, H., Zhang, S., Bellouin, N., Guttikunda, S. K., Hopke, P. K., Jacobson, M. Z., Kaiser, J. W., Klimont, Z., Lohmann, U., Schwarz, J. P., Shindell, D., Storelvmo, T., Warren, S. G., and Zender, C. S.: Bounding the role of black carbon in the climate system: a scientific assessment, J. Geophys. Res.-Atmos.,118, 5380-5552, doi:10.1002/jgrd.50171, 2013.

Cheng, M.-D.: Geolocating Russian sources for Arctic black carbon, Atmos. Environ., 92, 398-410, doi:10.1016/j.atmosenv.2014.04.031, 2014.

Committee for the Fishery Complex of the Murmansk Region: The state program of Murmansk Region "The Development of Fishery Complex of Murmansk region for 2014-2020”, Murmansk, Russia, 2013 (in Russian).

Corbett, J. J., Lack, D. A., Winebrake, J. J., Harder, S., Silberman, J. A., and Gold, M.: Arctic shipping emissions inventories and future scenarios, Atmos. Chem. Phys., 10, 9689-9704, doi:10.5194/acp-10-9689-2010, 2010.

EEA: EMEP/EEA Air Pollutant Emission Inventory Guidebook 2009, European Environment Agency, Copenhagen, Denmark, 2009.

EEA: EMEP/EEA Air Pollutant Emission Inventory Guidebook 2013, European Environment Agency, Copenhagen, Denmark, 2013.

Emisia: COPERT 4 (Computer programme to calculate emissions from road transport), Prepared for the European Environment Agency (EEA), available at: http://www.emisia.com/ content/copert-download (last access: 15 July 2014), 2011.

EPA: Report to Congress on Black Carbon, US Environmental Protection Agency, Washington, D.C., USA, EPA-450/R-12-001, 2012.

Evans, M., Kholod, N., Yu, S., Tretyakova, S., Gusev, E., and Malyshev, V.: Understanding black carbon from diesel sources in Russia: methodology for preparing an emissions inventory in Murmansk Region, PNWD-4400, Battelle - Pacific Northwest Division, Richland, WA, USA, 2012.

Government of the Murmansk Region: Strategy of Energy Saving in Murmansk Region, Murmansk, Russia, 2009.

GKS: Information about fuel use in Murmansk Region, Federal State Statistical Service, Moscow, Russia, 2012.

IEA: Fuel balances of non-OECD countries, International Energy Agency, Paris, France, 2012.

IPCC: IPCC good practice guidance and uncertainty management in national greenhouse gas inventories, Institute for Global Environmental Strategies, Hayama, Japan, 4-88788-000-6, 2000.

IPCC: 2006 IPCC guidelines for national greenhouse gas inventories, Institute for Global Environmental Strategies, Hayama, Japan, 4-88788-032-4, 2006.
Klimont, Z., Cofala, J., Bertok, I., Amann, M., Heyes, C., and Gyarfas, F.: Modeling particulate emissions in Europe. A framework to estimate reduction potential and control costs, International Institute for Applied Systems Analysis (IIASA), Laxenburg, Austria, 2002.

McCarty, J. L., Ellicott, E. A., Romanenkov, V., Rukhovitch, D., and Koroleva, P.: Multi-year black carbon emissions from cropland burning in the Russian Federation, Atmos. Environ., 63, 223 238, doi:10.1016/j.atmosenv.2012.08.053, 2012.

Minin, V.: Economic aspects of small-scale renewable energy development in remote settlements of the Kola Peninsula, Bellona Murmansk, Russia, 2012.

Mining Magazine: BELAZ at Apatity, Mining Magazine, UK, 47, October 2007.

Murmansk Port: Information System on State Port Control, available at: http://info.rs-head.spb.ru/webFS/regbook/ regbookVessel, last access: 29 July 2014.

NIIAT: Calculation instruction (methodology) for emission inventory from vehicles on the territory of the largest cities, Scientific Research Institute of Automobiles and Transportation, Moscow, Russia, 2008a (in Russian).

NIIAT: Calculation instruction (methodology) for emission inventory from vehicles into the air, Scientific Research Institute of Automobiles and Transportation, Moscow, Russia, 2008b (in Russian)

Novak, A. V.: The results of activity of the fuel and energy complex of Russia, The Ministry of Energy of the Russian Federation, Moscow, Russia, 2014.

Petrovich, A. A., Belyavskiy, D. A., and Garavskiy, A. O.: BELAZ trucks at open pit mines in Russia, Mining J., 1, 75-77, 2013 (in Russian)

Stohl, A., Klimont, Z., Eckhardt, S., Kupiainen, K., Shevchenko, V. P., Kopeikin, V. M., and Novigatsky, A. N.: Black carbon in the Arctic: the underestimated role of gas flaring and residential combustion emissions, Atmos. Chem. Phys., 13, 8833-8855, doi:10.5194/acp-13-8833-2013, 2013.

Streets, D. G., Bond, T. C., Lee, T., and Jang, C.: On the future of carbonaceous aerosol emissions, J. Geophys. Res.-Atmos., 109, D24212, doi:10.1029/2004jd004902, 2004.

The Russian Maritime Register of Shipping: The Register Book, Online database, available at: http://info.rs-head.spb.ru/webFS/ regbook/regbookVessel?ln=en, last access: 29 July 2014.

USDA: Developing Options for Avoiding, Reducing or Mitigating Agricultural Burning that Contributes to Black Carbon Deposition in the Arctic, United States Department of Agriculture, Washington, D.C., USA, 2012. 